\title{
Corporate Social Responsibility: Solution to Overcome Clean Water Availability Sustainable in Coastal City of Makassar City
}

\author{
Hafiz Elfiansyah Parawu ${ }^{1}$ \\ \{ hafiz@unismuh@ac.id ${ }^{1}$ \} \\ Universitas Muhammadiyah Makassar ${ }^{1}$
}

\begin{abstract}
The problem of clean water availability in coastal areas of Makassar City always happens every year and has not been resolved until now even though the Government of Makassar City has been doing a number of efforts to solve the problem. The low quality of service and the lack of clean water supply to the coastal communities is still a major obstacle. The limited ability of the Makassar City Government to solve this problem will require the participation of a number of companies, both BUMN and private, through Corporate Social Responsibility (CSR) program as a form of their awareness of the surrounding environment, especially related to the availability of clean water in the coastal area of Kota Makassar. A number of companies operating in Makassar City should be encouraged to actively participate in implementing their CSR in the form of a clean water supply program in the coastal area of Makassar City. If this CSR program can be realized, it is hoped that the availability of clean water in coastal areas will be fulfilled and the empowerment of coastal communities will be realized.
\end{abstract}

Keywords: corporate social responsibility, sustainable development, community empowerment

\section{Introduction}

International The current clean water service in the city of Makassar, has not been fully handled optimally, both in terms of the existing services, and the production capacity that is channeled to consumers. The water debit of Lekopancing Dam, Maros Regency, which is used as a source of raw water continues to decline until it has now become $265 \mathrm{~cm}$ from normal conditions. The raw water supply crisis in Makassar City PDAM to Panaikang Water Treatment Plant also occurs as a result of the dry season. Based on data from PDAM Kota Makassar, currently, water production at the Lekopancing Dam is in the range of 1,050 lps, which is usually 1,250-1,300 LPs [1].

Regions that are always experiencing a crisis of clean water in Makassar City are in coastal areas because they have very limited water resources, plus large-scale privatization and water use is actually carried out by industry, be it factories or hotels, most of which are in coastal areas. Not to mention the threat of seawater intrusion and disruption of groundwater quality due to poor environmental sanitation and pollution [2].

Residents in coastal areas, such as residents in Cambaya Village, Ujung Tanah District, Makassar City have difficulty getting clean water for daily household needs. Residents 
complained about water from the Regional Water Company (PDAM) which never flowed normally. They usually take water from family homes or other residents who still have good clean water flow. Residents of Tallo Village also experience water shortages and sometimes for four months the water does not flow, so they have to buy water from a water dealer at a price of Rp 5,000 per cart with 12 jerry cans per cart, while their daily water needs reach 3-5 carts [2].

Residents of Lakkang Village, TalloSubdistrict, Makassar City also often complain about the availability of clean water from the Makassar PDAM which can not flow to people's homes for days, so that conditions make people uneasy and have trouble getting clean water. To meet the needs of clean water, the residents were forced to buy water from the people who had clean water from the wells. There were also those who chose to fill jerry cans and buckets and then carried them with carts.

The results of Women's Monitoring related to the Right to Water held by AngingMammiri Women's Solidarity in 2016 involved 870 women in five villages in Makassar City, namely Cambaya, CambaBerua, Tallo, Buloa and Bangkala villages from November 2015-January 2016, finding that water availability, water quality, costs incurred, and water company services in fulfilling community water rights are some of the problems that occur in the community. The main water sources for the residents are generally from PDAMs (51.47\%), following private wells or drilled wells $(24.12 \%)$, water agents or traders $(23.98 \%)$, and private companies or bottled water $(0.42 \%)$ Regarding the availability of water, as many as 52.88 percent of residents consider the availability of water they get is not enough to meet their daily needs and as many as 50.91 percents of residents consider the quality of water they get from PDAMs is still far from decent standards. As many as $81 \%$ of residents stated that the cost they spent every month to get water was too expensive, between Rp. 300 thousand to Rp. 600 thousand per month [3].

\section{Result and Discussion}

\subsection{Corporate Social Responsibility (CSR)}

The concept of Triple Bottom Lines or 3P (Profit, Planet, People) initiated by Elkington in 1998, confirmed that a good company not only pursued mere economic profit (profit), but also cared for the environment (planet) and community welfare (people) sustainability. This means that the development of a company must pay attention to the development of society and the environment around the company's operating area, not just pursuing profit.

It is the company's obligation to care about the condition of the community and the environment that underlies the enactment of the Law of the Republic of Indonesia Number 40 of 2007 concerning Limited Liability Companies and the Government Regulation of the Republic of Indonesia Number 47 of 2012 concerning Social and Environmental Responsibility of Limited Liability Companies, where the company's social and environmental responsibilities This is limited which is better known as Corporate Social Responsibility (CSR). This policy stipulates that every company in carrying out its business activities is not pursuing profit only, but is also obliged to carry out social and environmental responsibilities on an ongoing basis, especially in the area of operations of the company.

Single definitions and specific criteria regarding the concept of CSR do not yet exist because the implementation and translation of CSR by companies also varies [4]. Defines CSR as a business commitment to act ethically, operate legally and contribute to improving the quality of life of employees and their families, local communities, and the wider community [5]. The European Commission defines CSR not only as an obligation, but is 
carried out voluntarily and there is a sincere urge from within and is an investment for the environment and stakeholders.

Defines CSR as the moral responsibility of a business organization to a group of stakeholders who are affected directly or indirectly from the company's operations [6]. Stated that CSR is a business activity that integrates economic, environmental and social aspects into values, culture, decision making, strategy and operations of the company that are carried out transparently and are responsible for creating a healthy and developing society [7].

A more comprehensive CSR view was made by Prince of Wales International Business Forum, through 5 (five) pillars, namely: (1) Building human capital, companies are required to create reliable (internal) $\mathrm{HR}$ and also do community empowerment (external); (2) Strengthening economics, namely empowering the community's economy so that there is equal distribution of people's welfare; (3) Assessing social cohesion, companies are required to maintain harmony with the surrounding community so as not to cause conflict; (4) Encouraging good governance, meaning that the company in running its business refers to good corporate governance (GCG); and (5) Protecting the environment, the company must maintain the environment [8].

Based on the various definitions that have been described, it can be concluded that CSR is the responsibility of the company not only to the survival of the company itself, but also to be responsible for the community and the surrounding environment by behaving ethically and morally so as to create a better quality of life.

\subsection{Sustainable Development and Community Empowerment}

The development of a country is not only the responsibility of the government. Every human being plays a role in realizing social welfare and improving the quality of life of the people. The business world plays a role in encouraging healthy economic growth by considering environmental factors [4]. Today's business world is no longer only paying attention to the company's financial records alone (single bottom line), but it includes social aspects and environmental aspects (triple bottom lines). The synergy of these 3 (three) elements is the key to the concept of sustainable development [9].

CSR development cannot be separated from the concept of sustainable development [10] CSR is one of the forms of business participation in sustainable development to develop a corporate awareness program for the surrounding community through the creation and maintenance of a balance between printing profits, social functions and environmental preservation [6].

CSR activities are related to sustainable activities. Elkington's view sustainability is a balance between people-planet-profit, known as $3 \mathrm{P}$ in the concept of the Tripple Bottom Lines, into an understanding of CSR that is relatively easier to understand and operationalize. Sustainability is located at a meeting between three aspects, people-social, planetenvironment, and economic profit [11].

Sustainable development according to WCED (World Commission on Environment Journal and Development is a development that meets the needs of the present without reducing the ability of future generations to meet their own needs. The Forum for the Future defines sustainable development as a path for human progress that has the capacity to continue [12]. According to The Brundtland Commission, sustainable development is development that can meet human needs today without sacrificing the ability of future generations to meet their needs [10]. This concept means, sustainable development aims so that future generations can also feel and enjoy the goodness of the environment that we feel today. concept of community 
empowerment includes the notion of community development and community-based development. Empowerment in the context of society is the ability of individuals who are compounded in society and build the empowerment of the community in question [13].

Empowerment includes various improvements, including [13]:

1) Better education

Improvements in material, methods, place and time, beneficiaries, and more importantly are improvements in education that can foster the spirit of lifelong learning;

2) Better accessibility

Improving accessibility with information/ innovation sources, financing sources, product and equipment providers, and marketing institutions;

3) Better action

Changing people's actions towards a better direction;

4) Better institution

Institutional improvements, including the development of partnership-business networks;

5) Better income

Change and increase business/ business community in a better direction;

6) Better education

Change and increase in family and community income in a better direction;

7) Better environment

Changes and improvements in the physical and social environment in a better direction;

8) Better living

Changes and improvement in the living conditions of every family and community in a better direction;

9) Better community

Changes and improvement in people's living conditions in a better direction.

\section{3 "Best Practices" Fulfillment of Clean Water Availability through CSR Programs in Indonesia}

The demands of the people and the development of democracy and the swift currents of globalization and free markets have led to awareness from the corporate world about the importance of implementing Corporate Social Responsibility [14]. In Indonesia alone, there are enough companies that carry out CSR obligations to fulfill the availability of clean water for the community, including those carried out by PT. Amerta Indah Otsuka as a pharmaceutical company related to nutraceutical nutrition. The implementation of the CSR program has been carried out since 2010 through the activities of "One Heart of Smarting the Nation" and "One Heart of Caring for the Environment". Pacarkeling Village Community Kejayan District Pasuruan District as the main target of CSR programs has obtained a number of benefits from the funding assistance used for clean water supply since 2012 for free.

PT. Ultrajaya Milk Industry \& Trading Company Tbk in Cimareme-Padalarang Bandung regency also realizes the importance of water for human survival so that one of the CSR programs they do is to provide some of the water they take to be distributed to the surrounding community in accordance with reasonable limits. Provision and provision of clean water is done by channeling it through pipes and accommodated in a storage tank placed in each 
village around the company. Villagers also enjoy clean water through pipes connected to the nearest reservoir from their settlements.

Semen Indonesia Ltd. has also started its CSR program since 2002. One of its flagship programs is in the field of public facilities development. CSR programs in this field are carried out in the form of physical development in the form of improvements to public infrastructure, provision of clean water, and improvement of rural community roads. Especially for the provision of clean water, the CSR activities carried out were the construction of culverts, repair of public toilets, and the manufacture of a number of wells for the needs of clean water for residents in the ring 1, ring 2 and ring 3 areas.

Aqua Golden Group Ltd. has also carried out CSR activities through an Integrated Water Resource Management program which has been developed since 2006 from a watershed-based water resource management model starting from the upstream (water supplemented area), central (Aqua water source area), to downstream. The water resources management program and access to clean water conducted in 2007 carrying the slogan "1L Aqua for 10L of Clean Water", has succeeded in helping 10 liters of clean water for four sub-districts in South Central Timor, East Nusa Tenggara, which is experiencing scarcity clean water for the needs of everyday life.

The best practices are also shown by Pertamina Ltd. by submitting some CSR assistance in the form of clean water facilities for the community around Air Manis Beach, West Sumatra. Air Manis Beach is one of the tourist destinations in the city of Padang, but unfortunately, the condition of the community is still experiencing problems to get clean water for their daily needs. The surrounding community must climb the hill first to get clean water, plus sanitation facilities are not enough. As a form of corporate social responsibility, Pertamina helps to provide 10,000 liters of clean water storage facilities along with its distribution pipeline network. This facility is able to meet the needs of clean water for 250 households, while to reduce the constraints of access to clean water is supported by pipelines that lead to the four distribution points with each of the five taps.

A number of CSR practices in addressing the availability of clean water for people in various regions in Indonesia, especially in this coastal area, are clear evidence that the contribution of the private sector in utilizing their CSR funds is so important and meaningful.

2.4. Fulfillment of the Availability of Clean Water in the Coastal Area of Makassar City through the CSR Program

Clean Water is water that is used for everyday purposes and its quality meets the health requirements of clean water in accordance with the applicable laws and regulations and can be drunk if cooked (Decree of the Minister of Health of the Republic of Indonesia Number 1405 of 2002 concerning Health Requirements for Office and Industrial Work Environment). Increasing population and development activities have resulted in a sharp increase in the need for clean water. On the other hand, the availability of clean water is increasingly limited even in some places experiencing a clean water crisis. All of this happened due to the declining quality of the environment, such as pollution, deforestation, changes in land use, etc.

Community needs for clean water have been trying to be fulfilled by the government through the PDAM, but this only applies to urban communities. The fulfillment of the need for clean water for coastal communities has not been fulfilled optimally, so that coastal communities use a lot of groundwater or rainfed which are not guaranteed to be quality because they are contaminated from the deteriorating quality of the environment. The main 
problems faced by water resources include the quantity of water that is not able to meet the ever-increasing needs and decreasing water quality for household needs.

Cambaya, CambaBerua, Buloa, Tallo, and Lakkang villages are a number of coastal areas in the city of Makassar that are in dire need of clean water. Communities in some of these areas each year experience a clean water crisis, especially in the dry season. The Makassar City PDAM has not been able to optimally meet the needs of clean water for this coastal community, so assistance from the private sector is needed. Fulfillment of the availability of clean water for coastal communities must certainly be realized not only the responsibility of the government alone but also the responsibility of the private sector or the company.

Every company has CSR funds that function to improve development and community welfare, including coastal communities. CSR funds can be used for the construction of clean water facilities and simultaneously enhance the empowerment of coastal communities in a sustainable manner. The powerlessness or poverty experienced by most coastal communities is caused by infrastructure poverty and family poverty. Infrastructure poverty in the form of the availability of physical infrastructure which is generally still very minimal such as the unavailability of clean water, far from the market and the lack of access to get fuel that meets the standard price. Meanwhile, family poverty is in the form of low levels of family income so that they cannot afford to fulfill their basic needs. When clean water is not available it will force families to spend money to buy clean water, and this means reducing their income.

To assist the Makassar City government in meeting the needs of clean water for coastal communities, the private sector or companies operating in the Makassar City area can utilize their CSR funds to supply clean water needs, especially during the dry season. Construction of a distribution pipeline or building a clean water reservoir that can be easily reached by all people in coastal areas can also be done. And also, it can carry out the construction of bore wells or groundwater wells and the construction of infiltration wells at a number of certain points.

CSR funds from private parties or companies operating in the Makassar City area can also be used to build a Water Treatment Plant with Reverse Osmosis (IPA RO) system. This installation can process brackish/salty water into clean water that is suitable for consumption for the community, especially for coastal communities. This refinery can change salty seawater and mix mud into clean drinking water which in terms of aroma and taste is truly worthy of consumption due to the use of such sophisticated refineries.

The utilization of CSR funds to meet the needs of clean water for the people in the coastal area of Makassar City is expected not only to be a solution to overcome the clean water crisis that hits the coastal communities every year, but it is also expected to improve the empowerment of coastal communities in a sustainable manner. In order to realize these expectations, it is important to conduct a partnership program between the government and the private sector, educational institutions, non-governmental organizations (NGOs), and the community itself. Through this partnership program, the management and utilization of CSR funds can be increasingly directed to address the availability of clean water while simultaneously enhancing the empowerment of coastal communities.

\section{Conclusion}

Fulfillment of the availability of clean water for coastal communities is not only the responsibility of the government but also the responsibility of the private sector or the company. CSR fund utilization from the private sector or companies operating in the Makassar City area can be used for the provision and construction of clean water facilities, 
such as clean water supply, construction of distribution pipelines and clean water storage tanks, construction of boreholes or groundwater wells and well-building infiltration wells, as well as building a Water Treatment Plant with Reverse Osmosis system (IPA RO). An important partnership program is also to be done so that in addition to being a solution to overcome the clean water crisis, CSR funds can also improve the empowerment of coastal communities in a sustainable manner.

\section{References}

[1] Fajar.co.id, "Makassar Utara Dan Timur Kota Makassar Kini Krisis Air Bersih)," 2018. .

[2] W. Chandra, "Masyarakat Pesisir Sulsel Makin Sulit Air. Kenapa?," 2018. .

[3] Nn, "Solidaritas Perempuan Anging Mammiri. Hasil Pemantauan Perempuan terkait Hak Atas Air." 2016.

[4] E. Sumardiyono, "Evaluasi Pelaksanaan Community Development dalam Perolehan PROPER Hijau (Studi Kasus di PT Pupuk Kaltim Bontang)," in Penelitian Ilmu Lingkungan Program Pascasarjana Universitas Diponegoro, 2007.

[5] L. Anatan, "Corporate Social Responsibility (CSR): TinjauanTeoritis dan Praktik di Indonesia," 2009. .

[6] D. A. Setyaningrum, "Pengaruh Implementasi Corporate Social Responsibility terhadap Kesejahteraan Hidup Masyarakat (Studi Kasuspada PT. Apac Inti Corpora, Bawen)," in Penelitian Program Sarjana Fakultas Ekonomi Universitas Diponegoro, 2011.

[7] R. Ratnasari, "Corporate Social Responsibility, Tanggung Jawab Sosial atau Strategi Perusahaan?," 2012.

[8] R. Triastity, "Bisnis danTanggung Jawab Sosial," J. Ekon. dan Kewirausahaan, vol. 10, no. 1, pp. 32-41, 2010.

[9] A. K. Irwanto and A. . Prabowo, "KajianEfektivitas Program Corporate Social Responsibility (CSR) Yayasan Unilever Indonesia," J. Manaj., vol. 1, no. 1, pp. 99110, 2009.

[10] R. Rahmatullah, "Pengelolaan Program Corporate Social Responsibility (CSR) pada Sektor Pertambangan," 2010.

[11] E. Suharto, CSR dan Comdev Investasi Kreatif Perusahaan di Era Globalisasi. Bandung: Alfabeta, 2010.

[12] M. F. Cahyandito, "Pembangunan Berkelanjutan, Ekonomi dan Ekologi, Sustainability Communication, dan Sustainability Reporting." 2006.

[13] T. Mardikanto and P. Soebiato., Pemberdayaan Masyarakat dalam Perspektif Kebijakan Publik. Bandung: Alfabeta, 2013.

[14] A. Haris, A. Adys, and A. Prianto, "Pengelolaan Corporate Social Responsibility PT. Lonsum di Kecamatan Ujung Loe Kabupaten Bulukumba," Otoritas J. Ilmu Pemerintah., vol. 4, no. 1, 2014. 